\title{
PENGARUH ATRIBUT SUPERMARKET TERHADAP MOTIF BELANJA HEDONIK MOTIF BELANJA UTILITARIAN DAN LOYALITAS KONSUMEN
}

\author{
Hartono Subagio \\ Progdi Manajemen Bisnis, Fakultas Ekonomi, Universitas Kristen Petra \\ Jl. Siwalankerto 121-131, Surabaya \\ Email: hartono@petra.ac.id
}

\begin{abstract}
Abstrak: Atribut supermarket menjadi perangsang motif pembelanja membeli produk, motif pembelian barang diklasifikasikan dalam Hedonik dan motif Utilitarian. Pemuasan motif hedonik maupun utilitarian menjadikan pembelanja setia kepada supermarket. Manfaat dari studi ini mengaplikasikan teori Stimulus Organism Response yang dikemukakan Mehrabian Russel, konsep ini juga dikembangkan oleh Baker dan Donovan, dan konsep Hedonik dari Arnold Reinold. Studi ini dilakukan disupermarket besar di Surabaya. Respon konsumen dan persepsi untuk menjawab pertanyaan dan hipotesanya diuji dengan analisa SEM. responden diambil 200 menurut syarat maksim likehood . Hasil studi memperlihatkan bahwa atribut supermarket berpengaruh terhadap motif hedonik dan motif utilitarian, dan loyalitas konsumen. Temuan empiris dari studi ini bahwa motif hedonik lebih kuat dari motif utilitarian terhadap kesetiaan konsumen.
\end{abstract}

Kata kunci: atribut supermarket, motif hedonik, motif utilitarian dan loyalitas.

\begin{abstract}
Attributes Supermarket stimulate the motive shopper to buying product, the motive Consuming and buying motives are classified into Hedonic and utilitarian. The fulfilness of hedonic and utilitarian motives lead to shoppers' loyalty to the supermarket. The purpose of the study is to review the theory of Stimulus Organism Response addressed by Mehrabian Russel, the concept of shopping motive developed by Baker and Donovan, and the concept of motive shopping Hedonic by Arnold Reynold. It was Empirical study on Big Supermarket in Surabaya. The Human behavior response and perceptional answers as well as concerned with inter variable effects through hypothesis tests by means of SEM analysis. The maximum likelihood estimation was derived from 200 respondents. The result $s$ of the study showed that atribute supermarket significanly affected motive Hedonic and motive Utilitarian and loyalty. The empirical findings from the study showed to motive Hedonic more strongth impact than motive utilitarian.
\end{abstract}

Kaywords: attibutes, motive hedonik, motif utilitarian, and loyalty.

\section{PENDAHULUAN}

Perubahan kebiasaan berbelanja sebagai bentuk mencari suatu kesenangan adalah merupakan suatu motif berbelanja baru. Motivasi merupakan konsepsi yang dinamis yang terus-menerus berubah sebagai reaksi terhadap berbagai pengalaman hidup. Kebutuhan dan sasaran terus-menerus bertumbuh dan berubah sebagai jawaban terhadap keadaan fisik, lingkungan, pengalaman, dan interaksi individu dengan orang lain. Ketika indiividu mencapai tujuannya mereka terus memperjuangkan tujuan lama, atau tujuan pengganti . Beberapa alasan mengapa kebutuhan tidak pernah berhenti adalah sebagai berikut:

1. Banyak kebutuhan yang tidak terpuaskan sepenuhnya. Kebutuhan tersebut terus mendorong tindakan yang dimaksudkan untuk mencapai atau mempertahankan kepuasan.

2. Setelah kebutuhan terpuaskan kebutuhan baru dan yang urutannya lebih tinggi timbul yang menyebabkan tekanan dan mendorong kegiatan.
3. Orang-orang yang berhasil mencapai tujuan mereka mmenetapkan tujuan baru dan lebih tinggi untuk diri mereka. Ketiga alasan itulah yang menyebabkan kebutuhan tidak pernah berhenti dan motif untuk memuaskannya tidak pernah berhenti tetapi terus berjalan dan dinamis.

Fenomena di atas merupakan alasan mengangkat topik penelitian motif belanja ke supermarket, baik motif hedonik maupun motif utilitarian untuk keputusan pembelian maupun pembelian ulang pada supermarket tertentu.

Pendapat Engel et al., (1994 : 284) motif belanja dimulai dari munculnya kebutuhan tertentu, yang semakin lama kebutuhan ini akan mendesak orang tersebut untuk dipenuhi. Desakan atau dorongan kebutuhan menjadi motivasi. Motivasi pembelian dan konsumsi diklasifikasikan dalam bentuk dua jenis yaitu motif hedonik dan Utilitarian. Motif belanja hedonik didasarkan pada emosi, perasaan nyaman, gembira, bersuka. Sedangkan motif belanja utilitarian 
didasarkan pada motif kemanfaatan fungsi belanja. Pemenuhan motif hedonik dan utilitarian akan berakibat pada kesetiaan pembelanja kepada supermarket yang menyajikan tawaran yang mampu menyesuaikan dengan dorongan atau motif hedonik atau motif utilitarian pembelanja. Penelitian yang dilakukan Nguyen et al. (2007) membuktikan pengaruh motif belanja Hedonik, dan atribut supermarket terhadap loyalitas pembelanja supermarket di Vietnam. Penelitian ini menggunakan penelitian Nguyen et al., (2007) sebagai sumber acuan yang juga meneliti pengaruh atribut supermarket, motif belanja hedonik dan motif belanja utilitarian terhadap loyalitas pembelanja supermarket. Penelitian ini juga dilandasi oleh model respon organism terhadap stimulus (Stimulus organism Response) yang dikemukakan oleh Mehrabian and Russel (1974). Model stimulus organism Response menjelaskan tentang mekanisme pengaruh elemen lingkungan terhadap kondisi internal individu dan kemudian mempengaruhi perilaku individu bersangkutan. Stimulus adalah input yang memasuki kelima indra manusia. Stimulus mempunyai tiga elemen yaitu Ambient, design dan social. Dalam penelitian ini atribut supermarket merupakan salah satu stimulus yang meliputi faktorfaktor Ambient, design dan social. Ambient adalah kenyamanan suasana yang dirasakan pembelanja saat mengamati barang dan jasa yang ditawarkan. Design adalah rancangan fisik supermarket yang meliputi tatanan layout dan fungsinya, tanda dan simbol, keindahan seperti tatanan warna dan visual yang memberikan kenyamanan kepada pembelanja termasuk juga penempatan posisi, eskalator, lift dan elemen arsitek lainnya. Faktor social adalah faktor yang berkaitan dengan keberadaan karyawan dan pembelanja lainnya dalam supermarket yang bersangkutan, (Donovan et al.1982, Baker et al., 1992). Faktor sosial ini akan berdampak pada bagaimana penilaian pembelanja pada kualitas barang dan jasa serta citra supermarket tersebut. Berdasarkan beberapa pertimbangan, penelitian ini memberikan komponen attribut, sebagai indikator yang paling banyak digunakan adalah pertama atmosfir supermarket meliputi fassilitas fisik supermarket, suhu, layout, dan display, kedua lokasi supermarket kemudahan mencapai, letak strategis, fasilitas transportasi, ketiga adalah fasilitas kemudahan, parkir, pembayaran, pengembalian barang, keempat adalah layanan pramuniaga responsif, empathi, reliabel, keramahan. Kelima adalah barang dagangan. Keaneka ragaman, kualitas dan harga, merek dan model.

Stimulus Organism Response model (S-O-R) merupakan suatu model yang menggambarkan individu melalui proses kognisi, yaitu, penilaian pem- belanja (persepsi) berdasarkan proses mental dan struktur pengetahuan sebagai tanggapan seseorang terhadap lingkungan (motif utilitarian). Evaluasi yang bersifat afeksi yaitu, berdasarkan perasaan senang menjadi motif Hedonik pembelanja (Mehrabian and Russel,1974). Perasaan (aspek afeksi) menseleksi kualitas lingkungan belanja dari sisi kenikmatan (enjoyment) yang dirasakan, rasa tertarik akibat pandangan mata (visual appeal) dan rasa lega (escapism). Motif belanja hedonik dikembangkan oleh Arnold and Reynolds (2003:80,81) dengan indikator meliputi pertama adalah adventure shopping. Belanja ada tantangan, suatu sensasi, menggembirakan, masuk lingkungan universal yang menyenangkan. Kedua adalah Social shopping. Sosialisasi adalah tujuan utama dari pembelanja ketika mereka pergi belanja. Ketiga adalah Gratification shopping. Kehidupan yang kompleks saat ini dan tingkat stres meningkat di masyarakat. Beberapa orang belanja untuk menghilangkan stress. Keempat adalah Idea Shopping. Berbelanja memberikan pengetahuan baru perkembangan trend baru dan model baru.

Kelima adalah Role shopping. Peranan belanja direfleksikan dalam kenikmatan, dipengaruhi oleh perasaan dan keadaan hati (moods). Keenam adalah Value shopping. Beberapa orang belanja untuk menemukan barang yang baik dan bernilai bagi dirinya.

Menurut kerangka kerja S-O-R (Stimulus Organism Response), respon perilaku dihasilkan dari penilaian internal konsumen. Respon perilaku meliputi pendekatan fisik, kinerja kerja, eksplorasi, dan interaksi sosial. Dalam hal ini adalah sikap loyal terhadap supermarket yang diwujudkan dalam, penggunaan waktu lebih banyak untuk belanja, kecenderungan membelanjakan uang lebih banyak dari yang direncanakan semula, berniat belanja kembali dikemudian hari dan merekomendasikan kepada teman dan saudara.

Rangsangan didalam supermarket memberikan informasi penting yang mendorong konsumen untuk membentuk penilaian tentang harga, produk dan jasa didalam supermarket. Menurut Baker et al. (1994) penilaian pembelanja atas mutu barang dan jasa dan kenyamanan dalam supermarket menyebabkan motif utilitarian yang makin meningkat. Singh (2006) dalam penelitiannya membuktikan bahwa stimulus atau rangsangan mempengaruhi motif pembelian utilitarian yang diukur dengan evaluasi kognitif dan juga stimulus atau rangsangan mempengaruhi motif hedonik yang dievaluasi afektif dan keduanya berpengaruh berbeda dalam perilaku belanja yaitu memberikan waktu didalam supermarket lebih lama 
untuk belanja dan pembelian ulang. Motif Hedonik adalah dasar untuk mengevaluasi pengalaman belanja lebih dari informasi yang mereka kumpulkan atau produk yang dibeli. Konsumen berbelanja mencari kesenangan, Motif Hedonik berbelanja tidak hanya untuk membeli barang tetapi juga kegiatan sosialisasi dengan teman untuk mencari hiburan. Manfaat Hedonis adalah manfaat yang bersifat perasaan yaitu perasaan senang, perasaan lega, perasaan nikmat. (Mehrabian and Russel, 1974)

Pada model S-O-R Motif belanja utilitarian didasarkan pada evaluasi kognisi atau kepikiran seseorang untuk mempengaruhi manusia dengan cara mana menjadi rangsangan dan mendorong perilaku. Motif utilitarian adalah evaluasi yang menilai kualitas barang dagangan, kualitas layanan, harga yang ditetapkan dan efisiensi belanja. Meharabian and Russel (1974) motivasi belanja menarik pembelanja untuk datang ke pasar tempat memuaskan kebutuhannya dan mempunyai hubungan langsung dengan kesetiaan belanja (Babin et al.1994) Konsumen yang mendapat pengalaman pada pasar modern seperti supermarket mendapatkan pengalaman kemudahan, modern, dan tempat yang menyenangkan untuk belanja. Fenomena Pelanggan yang mendapatkan nilai atau manfaat, dan layanan sebagai atribut supermarket yang ditawarkan kepada konsumen yang berkunjung, dan melakukan pembelian ulang sehingga, permasalahan yang dapat diidentifikasikan adalah, bahwa atribut supermarket mempengaruhi loyalitas pembelanja supermarket. Berdasarkan fenomena bahwa pembelanja akan berkunjung dan melakukan pembelian ulang oleh karena didorong oleh motif yang bersifat fungsional dan motif yang bersifat hedonik sehingga permasalahan yang dapat diidentifikasikan adalah sebagai berikut diketahui ada pengaruh dari motif hedonik dan utilitarian konsumen terhadap loyalitas pembelanja supermarket. Sehingga
Motif belanja Hedonik dan Utilitarian terhadap Loyalitas Pembelanja dengan aspek Pendapatan sebagai variabel Moderator studi pada Supermarket di Surabaya.

\section{Perumusan masalah}

Setelah mengetahui fakta yang spesifik dan fenomena yang dihadapi, maka bisa diidentifikasikan masalah-masalah yang timbul.

Perumusan masalahnya adalah sebagai berikut:

1. Apakah attribut Supermarket berpengaruh signifikan terhadap motif belanja hedonik pembelanja supermarket di Surabaya?

2. Apakah atribut Supermarket berpengaruh signifikan terhadap motif belanja utilitarian pembelanja supermarket di Surabaya?

3. Apakah attribut Supermarket berpengaruh signifikan terhadap loyalitas pembelanja supermarket di Surabaya?

4. Apakah motif belanja hedonik berpengaruh signifikan terhadap loyalitas pembelanja supermarket di Surabaya.

5. Apakah motif belanja utilitarian berpengaruh signifikan tehadap loyalitas pembelanja supermarket di Surabaya?

\section{TINJAUAN PUSTAKA}

\section{Model Umum tentang Motivasi}

Model umum tentang variabel-variabel interdepensi yang bersifat dasar bagi motivasi disajikan pada Gambar 1.

Model ini merupakan sebuah kerangka kerja untuk memahami sifat dinamik dari proses motivasi. Menurut teori kebutuhan, seseorang termotivasi apabila ia belum mencapai tingkat kepuasan tertentu

Sebuah model umum tentang proses motivasi

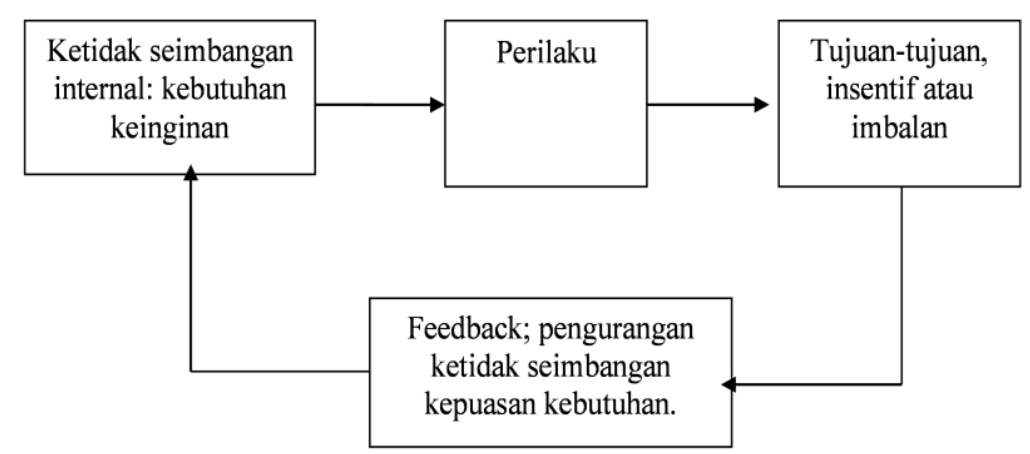

Gambar 1. Sebuah model umum tentang proses motivasi

judul penelitian adalah Pengaruh Atribut supermarket, dengan kehidupannya. Kebutuhan yang terpenuhi 
bukanlah sebuah motivator. Perilaku pada dasarnya berorintasi pada tujuan, dengan kata lain perilaku kita pada umumnya dimotivasi oleh keinginan untuk mencapai tujuan tertentu. Adapun tujuan spesifik tidak senantiasa diketahui secara sadar oleh individu. Kebutuhan-kebutuhan berhubungan dengan kekurangan-kekurangan yang dialami seorang individu pada titik waktu tertentu.

\section{Perilaku}

Perilaku pada dasarnya berorintasi pada tujuan, dengan kata lain perilaku kita pada umumnya dimotivasi oleh keinginan untuk mencapai tujuan tertentu. Adapun tujuan spesifik tidak senantiasa diketahui secara sadar oleh individu. Alasan tindakantindakan kita tidak selalu jelas bagi pemikiran kita secara sadar. Dorongan-dorongan (drives) yang memotivasi pola-pola perilaku individu hingga tingkat tertentu berlangsung dibawah sadar karena tidak mudah untuk mengevaluasi. Dalam banyak situasi kita melakukan lebih dari satu macam kegiatan pada saat bersamaan, seperti kita berbicara dengan orang lain sewaktu kita belanja ke supermarket. Setiap saat kita mungkin membeli sesuatu yang tidak direncanakan, kita mungkin memutuskan untuk beralih dari satu aktivitas tertentu atau kombinasi aktivitas-aktivitas untuk melaksanakan hal-hal lain.

\section{Model Stimulus organism response ( S-O-R )}

Model Rangsangan manusia dan tanggapan (stimlus organism response) yang dikemukakan oleh Mehrabian and Russell 1974. menentukan hubungan antara lingkungan fisik dan perilaku individu. Kerangka kerja rangsangan manusia dan tanggapan (Stimulus Organism Response) menggambarkan mekanisme untuk bagaimana elemen lingkungan mempengaruhi keadaan internal dan mempengaruhi perilaku individu yang bersangkutan. Elemen lingkungan adalah stimulus yang memberikan dorongan (stimuli) kepada individu untuk melakukan evaluasi. Pada penelitian pengaruh dorongan (stimulus) salah satu stimulus adalah atribut supermarket merupakan nilai konsumen. Lingkungan supermarket diselaraskan penggunaannya sebagai atribut supermarket, hubungan ini melalui penilaian kualitas barang yang dijual dan harga yang ditetapkan. Baker et al. (2002) berpendapat bahwa persepsi kualitas yang tinggi berpengaruh positif terhadap persepsi nilai barang dagangan, dimana tingginya persepsi harga akan mengakibatkan hubungan yang negatif terhadap nilai konsumen. Pandangan dari hubungan nilai atmosfir dijelaskan bahwa proses mengukur nilai oleh konsumen tentang produk dan didasarkan pada dorongan (stimulus) eksternal pada atribut supermarket. Konsumen dalam membuat penilaian yang dipertimbangkan dipengaruhi tanggapannya terhadap kinerja supermarket. Pada konsep dasar kerangka kerja S-O-R, atribut supermarket adalah lingkungan atau atmosfir yang menjadi dorongan rangsangan (Stimulus) menjadi acuan evaluasi konsumen terhadap supermarket.

Lingkungan supermarket memiliki sejumlah (Stimulus) atau atribut yang dapat menciptakan suasana yang merangsang pembelanja melakukan pembelian, yaitu lingkungan yang dirancang untuk menghasilkan pengaruh emosi dari pembeli untuk mendorong mereka melakukan pembelian.

\section{Komponen Stimulus (Komponen lingkungan fisik supermarket).}

Lingkungan supermarket sebagai stimuli mempunyai tiga elemen yaitu Ambient, design dan social. Dalam penelitian ini atribut supermarket merupakan salah satu stimulus yang meliputi faktor-faktor

\section{Kerangka kerja S-O-R dalam lingkungan fisik toko}

\begin{tabular}{|l|l|l|}
\hline $\begin{array}{l}\text { Stimulus } \\
\text { Ambient } \\
\text { Design } \\
\text { social }\end{array}$ & $\begin{array}{l}\text { Organism Cognitive } \\
\text { Evaluations } \\
\text { Merchandise Quality } \\
\text { Price } \\
\text { Service quality } \\
\text { Efficiency } \\
\text { Affective Evaluation } \\
\text { Enjoyment } \\
\text { Visual appeal } \\
\text { Escapism }\end{array}$ \\
\hline
\end{tabular}

Sumber: Mehrabian and Russel 1974

Gambar 2. Kerangka kerja S-O-R dalam lingkungan fisik toko 
Ambient, design dan social. Ambient adalah kenyamanan suasana yang dirasakan pembelanja saat mengamati barang dan jasa yang ditawarkan. Design adalah rancangan fisik supermarket yang meliputi tatanan layout dan fungsinya, tanda dan simbol, keindahan seperti tatanan warna dan visual yang memberikan kenyamanan kepada pembelanja termasuk juga penempatan posisi,eskalator, lift dan elemen arsitek lainnya. Faktor social adalah faktor yang berkaitan dengan keberadaan karyawan dan pembelanja lainnya dalam supermarket yang bersangkutan. (Donovan et al., 1982, Baker et al., 1994). Faktor sosial ini akan berdampak pada bagaimana penilaian pembelanja pada kualitas barang dan jasa serta citra supermarket tersebut. Berdasarkan beberapa pertimbangan, penelitian ini memberikan komponen attribut, sebagai indikator yang paling banyak digunakan adalah pertama atmosfir supermarket meliputi fassilitas fisik supermarket, suhu, layout, dan display, kedua lokasi supermarket, kemudahan mencapai, letak strategis, fasilitas transportasi, ketiga adalah fasilitas kemudahan, parkir, pembayaran, pengembalian barang, keempat adalah layanan pramuniaga responsif, empathi, reliabel, keramahan. Kelima adalah barang dagangan. Keaneka ragaman, kualitas dan harga, merek dan model.

\section{Organism, Evaluasi afeksi dan kognisi.}

Afeksi (Affect) mengacu pada evaluasi perasaan, sementara kognisi (cognitive) terdiri dari evaluasi mental (pemikiran) Konsumen dapat memiliki sekaligus evaluasi afektif dan kogntif, walaupun kedua sistem tersebut berbeda, namun mereka saling terkait, dan setiap sistem dapat mempengaruhi serta dipengaruhi oleh yang lainnya. Afeksi adalah keberadaan seseorang atau sesuatu yang dirasakan seseorang (senang, sedih, dan bosan). Sebaliknya,orang memiliki kognisi, pemikiran atau kepercayaan. Sebagai suatu status mental, kognisi biasanya tidak terletak pada tubuh manusia (eksternal). Orang dapat mengalami empat jenis tanggapan afektif, emosi, perasaan tertentu, suasana hati dan evaluasi. Setiap jenis afeksi dapat melibatkan tanggapan positif atau negatif. Semakin kuat tanggapan afeksi, termasuk perasaan senang, sedih, gembira. Suasana hati, yang melibatkan reaksi fisiologis yang tidak begitu gencar. Suasana hati, yang melibatkan intensitas perasaan paling rendah cenderung merupakan suatu status afektif yang kabur. Akhirnya evaluasi terhadap produk atau konsep lainnya seringkali suatu tanggapan afeksi yang lemah. Mehrabian and Russel (1974) mengemukakan bahwa respon afeksi menimbulkan motif hedonik pembelanja. Perasaan (aspek afeksi) menseleksi kualitas lingkungan belanja dari sisi kenikmatan (enjoyment) yang dirasakan, rasa tertarik akibat pandangan mata (visual appeal) dan rasa lega (escapism).

\section{Tanggapan perilaku (response behavior)}

Pendekatan penghindaran dari respon konsumen adalah waktu yang dipakai untuk memilih, mengekplorasi supermarket dan niat melakukan pembelian kembali. Sependapat dengan Mehrabian and Russel (1974) Didalam konteks eceran reaksi emosi mempengaruhi waktu yang diluangkan didalam eksplorasi didalam supermarket, kecenderungan untuk mengeluarkan uang lebih banyak dari yang direncanakan semula, dan berniat kembali datang ke supermarket dikemudian hari. Selanjutnya Donovan et al. (1994) menemukan bahwa kenyamanan sangat signifikan dengan menentukan waktu tambahan dan pembelian yang tidak direncanakan didalam supermarket. Didalam evaluasi pengalaman belanja, Baker et al. (2002) mendapati bahwa korelasi negatif antara biaya (waktu, usaha, uang) dengan niat kembali membeli. Menurut kerangka kerja S-O-R (stimulus organism response), respon perilaku dihasilkan dari penilaian internal konsumen. Respon perilaku meliputi pendekatan fisik, kinerja kerja, eksplorasi, dan interaksi sosial. Dalam hal ini adalah sikap loyal terhadap supermarket yang diwujudkan dalam, pemakaian waktu lebih banyak untuk belanja, kecenderungan mengeluarkan uang lebih banyak dari yang direncanakan semula, berniat datang kembali dikemudian hari dan merekomendasikan kepada teman dan saudara. Indikator loyalitas pembelanja supermarket adalah pertama loyalitas diukur dengan mempertimbangkan pembelian kembali. Kedua adalah mengeluarkan uang lebih banyak di supermarket jika membutuhkan barang. Ketiga adalah bersedia merekomendasikan supermarket kepada keluarga dan kolega.

\section{Konsep Atribut Supermarket}

Pada penelitian ini pengaruh dorongan (stimulus) adalah atribut supermarket yang merupakan stimuli yang berasal dari eksternal mempengaruhi evaluasi penilaian individu. Lingkungan supermarket diartikan sebagai atribut supermarket. Atribut supermarket adalah stimuli yang meliputi ambient, design, dan social, atau dipandang sebagai bagian keseluruhan citra supermarket itu (Bloemer and Schroeder, 2002).

Koo (2003) menyarankan tujuh komponen untuk atribut supermarket seperti atmosfir toko, lokasi, fasilitas kemudahan, nilai, layanan pramuniaga, layanan 
purna jual, dan barang dagangan. Pada penelitian ini atribut dengan indikator komponen fasilitas fisik, layanan pramuniaga, layanan purna jual, barang dagangan. Fasilitas fisik yang tersedia di pasar swalayan seperti phisik bangunan, layout, dan display. Kategori ini juga meliputi kemudahan, seperti lokasi yang mudah, tempat parkir. Layanan pramuniaga lebih pada kualitas yang disediakan oleh karyawan pasar swalayan, sedangkan layanan purna jual meliputi fasilitas penukaran barang yang tidak cocok dan kebijakan pengembalian uang, dan barang dagangan lebih pada kualitas produk yang dijual, macam merek dan ketersediaan barang persediaan.

\section{Konsep Motif Belanja Hedonik}

Motif belanja hedonik adalah kebutuhan tiap individu akan suasana dimana seseorang merasa bahagia, senang. Selanjutnya kebutuhan akan suasana senang tersebut menciptakan arousal, mengacu pada tingkat dimana seseorang merasakan siaga, digairahkan, atau situasi aktif

Mehrabian and Russel (1974) mengemukakan bahwa respon afeksi menimbulkan motif hedonik pembelanja. Perasaan (aspek afeksi) menseleksi kualitas lingkungan belanja dari sisi kenikmatan (enjoyment) yang dirasakan, rasa tertarik akibat pandangan mata (visual appeal) dan rasa lega (escapism). Perasaan tersebut membuat seseorang senang atau Pleasure. Suasana dimana seseorang merasa bahagia senang, dicari orang karena merupakan kebutuhan tiap individu. Selanjutnya kebutuhan akan suasana senang tersebut menciptakan arousal, mengacu pada tingkat dimana seseorang merasakan siaga, digairahkan, atau situasi aktif, motif yang disebut motif Hedonik.

\section{Konsep Motif Belanja Utilitarian.}

Pembelanja sebagai umat manusia telah mengembangkan sistem kognitif sangat canggih yang mengungkapkan proses mental yang lebih tinggi untuk pengertian, penilaian, perencanaan, penetapan, dan berpikir. Motif belanja utilitarian merupakan suatu motif seseorang untuk mendapatkan harga, produk dan jasa layanan didalam supermarket dan efisiensi penggunaan waktu dan tenaga Evaluasi kognitif menggunakan kepikiran dalam mengukur motif utilitarian (Schifman and Kanuk, 2004; Engel et al., 1994) Motif utilitarian menekankan pada nilai belanja yang bermanfaat, sebagai sesuatu yang terkait dengan tugas, masuk akal, berhati-hati, dan efisiensi aktifitas. Selama proses ini konsumen menseleksi, mengorganisir, dan menginterpretasikan informasi dorongan dan meciptakan gambaran yang berarti dari supermarket tersebut Informasi tersebut dari stimulus yaitu atribut supermarket yang dievaluasi oleh motif utilitarian dengan mengevaluasi persepsi kualitass barang dan layanan supermarket dan harga yang ditetapkan.

\section{Konsep Loyalitas Pembelanja Supermarket}

Dapat dikatakan, loyalitas atau kesetiaan adalah sebuah komitmen mendalam untuk membeli kembali atau menjadi pelanggan tetap dari sebuah produk/jasa yang disukai secara konsisten di masa yang akan datang, di mana komitmen tersebut menyebabkan pembelian yang berulang terhadap produk yang sama, meskipun pengaruh-pengaruh situasional dan usahausaha pemasaran mempunyai kesanggupan atau kemungkinan untuk mengakibatkan perubahan perilaku. (Zeitham and Bitner, 2006)

Pada pendekatan sikap (attitudinal) loyalitas didasarkan atas komitmen psikologis, keinginan beli, dan rekomendasi dari mulut kemulut.

\section{METODE PENELITIAN}

\section{Rancangan Penelitian}

Penelitian ini menggunakan rancangan explanatory, merupakan suatu penelitian yang bertujuan untuk menjelaskan kenapa peristiwa terjadi dan untuk membangun, mengelaborasi, memperluas atau menguji teori dan menemukan penjelasan mengenai pengaruh/hubungan antara satu variabel dengan variabel lain dan melakukan pengujian hipotesis yang diajukan (Gay, 1999: 215).

\section{Populasi, Sample, Besar Sampel dan Teknik Pengambilan Sampel}

\section{Populasi penelitian}

Jumlah supermarket yang ada di Surabaya cukup besar dan tersebar, sedangkan yang mempunyai jumlah outlet terbanyak dan ukurannya paling besar adalah supermarket Carrefour, Hypermart dan Giant/Hero. Ketiga supermarket ini yang mempunyai penjualan terbasar dan paling dikenal masyarakat.

Dengan alasan demikian, penelitian ini dilakukan pada supermarket Carrefour, Hypermart dan Giant dikota Surabaya. Sampel diambil dari konsumen yang melakukan transaksi berbelanja pada Supermarket Carrefour, Hypermart, dan Giant/Hero Pengambilan responden di Supermarket dimaksud 
adalah karena jumlah gerai yang besar dan berada pada tiap pusat perbelanjaan di kota Surabaya.

Dalam penelitian ini dapat dikatakan bahwa Populasi penelitian bersifat infinit (tidak terbatas) karena masing-masing supermarket tidak mempunyai data secara pasti mengenai jumlah maupun data konsumennya.

\section{Penentuan Besar Sampel}

Keterwakilan populasi oleh sampel dalam penelitian merupakan syarat penting untuk melakukan generalisasi. Sehubungan dengan populasi penelitian ini yang bersifat infinit (tidak terbatas) dan digunakannya model persamaan dan digunakannya model persamaan struktural (Structural Equation Modelling) maka penentuan besar sampel penelitian ini menggunakan pertimbangan sebagai berikut:

\section{Model size}

Penentuan besar sampel penelitian yang ideal berdasarkan Hair et al. (1999 : 367) adalah 5 sampai dengan 10 kali jumlah indikator yang digunakan dalam seluruh variabel laten. Jumlah seluruh indikator yang digunakan dalam penelitian ini 19. Jadi responden yang disarankan adalah minimal 5 atau maksimal 10 kali indikator.pada penelitian ini minimal responden 19 × $5=95$ responden sampai jumlah maksimal $19 \times 10=190$ responden.

2. Maximum Likelihood Estimation.

Menurut Hair et al. (1999 : 372) jumlah responden yang ideal untuk Pemanfaatan maximum likehood estimation dalam model persamaan struktural adalah 200 responden. Jumlah sampel dalam penelitian ini ditetapkan sebesar 200 responden, berdasarkan pertimbangan untuk memenuhi ketentuan model size maupun maximum likehod estimation.

\section{ANALISIS HASIL PENELITIAN}

\section{Karakteristik Responden}

Pada bagian ini disajikan data dari hasil penyebaran kuesioner kepada responden. Kuesioner yang disebarkan sebanyak 220 kuisioner yang kembali sebanyak 210 kuisioner dan 200 kuisioner dapat digunakan untuk proses analisa data. Karakteristik responden yang dijadikan pada penelitian antara lain jenis kelamin, usia responden, status responden, pendapatan responden dan jumlah kunjungan responden. Data responden yang didapatkan bila di deskripsikan lebih lanjut untuk setiap karakteristik terdapat pada Tabel 1; Tabel 2; Tabel 3; Tabel 4; dan Tabel 5.

Tabel 1. Jumlah Responden Berdasarkan Jenis Kelamin

\begin{tabular}{lcc}
\hline Jenis kelamin & Jumlah & Persentase \\
\hline Pria & 96 & $46 \%$ \\
Wanita & 104 & $54 \%$ \\
\hline Total & 200 & $100 \%$ \\
\hline
\end{tabular}

Tabel 2. Karakteristik Responden Berdasarkan Usia

\begin{tabular}{lcc}
\hline Usia Responden & Jumlah & Persentase \\
\hline Kurang 18 tahun & 20 & $10 \%$ \\
18 sampai 24 tahun & 76 & $38 \%$ \\
25 sampai 30 tahun & 30 & $15 \%$ \\
31 sampai 35 tahun & 31 & $15,5 \%$ \\
36 sampai 40 tahun & 20 & $10 \%$ \\
Lebih dari 40 tahun & 23 & $11,5 \%$ \\
\hline Total & 200 & $100 \%$ \\
\hline
\end{tabular}

Tabel 3. Karakteristtik Responden Berdasarkan Status Perkawinan

\begin{tabular}{lcc}
\hline Status Responden & Jumlah & Persentase \\
\hline Bujangan & 94 & $47 \%$ \\
Kawin tidak punya anak & 19 & $10 \%$ \\
Kawin punya anak & 67 & $34 \%$ \\
Duda / janda & 20 & $10 \%$ \\
\hline Total & 200 & $100 \%$ \\
\hline
\end{tabular}

Tabel 4. Karakteristik Responden Berdasarkan Pendapatan

\begin{tabular}{lcc}
\hline Pendapatan Responden & Jumlah & Persentase \\
\hline kurang 1 Juta & 34 & $16 \%$ \\
1 sampai 3 Juta & 64 & $32 \%$ \\
3 sampai 5 Juta & 40 & $20 \%$ \\
5 sampai 10 Juta & 39 & $20 \%$ \\
Lebih dari 10 juta & 23 & $12 \%$ \\
\hline Total & 200 & $100 \%$ \\
\hline
\end{tabular}

Tabel 5. Karakteristik Responden Berdasarkan Kunjungan Responden Dalam Tiga Bulan Terakhir

\begin{tabular}{lrr}
\hline Kunjungan Responden & \multicolumn{1}{c}{ Jumlah } & Persentase \\
\hline Satu kali & 24 & $12 \%$ \\
Dua kali & 76 & $38 \%$ \\
Tiga kali & 36 & $18 \%$ \\
Lebih dari tiga kali & 64 & $32 \%$ \\
\hline Total & 200 & $100 \%$ \\
\hline
\end{tabular}

Berdasarkan pada Tabel 1 dapat di deskripsikan bahwa sebagian besar pengunjung supermarket di Surabaya adalah kaum wanita. Hasil kuisioner yang didapatkan berdasarkan jumlah responden didapatkan 104 responden wanita dan 96 responden pria. 
Tabel 6. Distribusi Frekuensi Pada variabel Atribut Supermarket

\begin{tabular}{|c|c|c|c|c|c|c|c|c|c|c|c|c|c|}
\hline \multirow{3}{*}{ Item-item } & \multicolumn{10}{|c|}{ Skor } & \multirow{2}{*}{\multicolumn{2}{|c|}{ Total }} & \multirow{3}{*}{ Rata-rata } \\
\hline & \multicolumn{2}{|c|}{1} & \multicolumn{2}{|c|}{2} & \multicolumn{2}{|c|}{3} & \multicolumn{2}{|c|}{4} & \multicolumn{2}{|c|}{5} & & & \\
\hline & f & $\%$ & $\mathbf{f}$ & $\%$ & $\mathbf{F}$ & $\%$ & $\mathbf{F}$ & $\%$ & $\mathbf{F}$ & $\%$ & $\mathbf{F}$ & $\%$ & \\
\hline X1.1 (Atm) & 0 & 0 & 7 & 4 & 22 & 11 & 156 & 78 & 15 & 7 & 200 & 100 & 3,81 \\
\hline X1.2 (Lok) & 1 & 1 & 9 & 5 & 60 & 30 & 88 & 55 & 18 & 9 & 200 & 100 & 3,69 \\
\hline X1.3 (Fas) & 1 & 1 & 8 & 4 & 59 & 30 & 114 & 56 & 18 & 9 & 200 & 100 & 3,71 \\
\hline X1.4 (layan) & 1 & 1 & 10 & 5 & 56 & 28 & 111 & 55 & 22 & 11 & 200 & 100 & 3,63 \\
\hline X1.5 (Merchan) & 0 & 0 & 9 & 5 & 62 & 31 & 116 & 57 & 13 & 7 & 200 & 100 & 3,72 \\
\hline \multicolumn{14}{|c|}{ Rata-rata frekuensi $=3,70$} \\
\hline
\end{tabular}

Karakteristik responden berdasarkan usia dibagi atas enam bagian, dimana didapatkan responden terbesar antara umur 18 tahun sampai dengan 24 tahun sebesar 76 responden yakni 38\% yang dikategorikan baik (Flesch dalam Monir, 2009).

Usia responden terendah terdapat pada umur kurang dari 18 tahun disebabkan peneliti berfokus pada responden yang telah berusia 18 tahun atau lebih.

Bila digambarkan karakteristik responden berdasarkan status terdapat pada Tabel 3, yang dibagi atas empat bagian, dan terbesar terdapat pada responden yang belum kawin sebesar 94 responden (47\%) dan kedua pada responden yang sudah kawin dan telah memiliki anak sebesar 34\%. Deskripsi ini memberikan gambaran bahwa yang telah melakukan transaksi belanja di supermarket adalah responden relatif berumur muda dan responden memiliki keluarga untuk memenuhi kebutuhan melalui pembelian di supermarket.

Deskripsi ini memberikan gambaran bahwa yang melakukan transaksi di supermarket Carrefour, Hypermart, dan Giant/Hero pada umumnya responden yang memiliki tingkat sosial menengah kebawah pendapatan dibawah 10 juta sebesar $88 \%$. Sedangkan bagi responden yang memiliki tingkat sosial kelas atas dengan pendapatan melebihi 10 juta perbulan relatif sedikit yakni 23 responden (12\%).

Pengunjung dari pasar modern ternyata lebih banyak mereka yang mempunyai pendapatan rendah sehingga pilihan harga relatif lebih sensitif, perbedaan harga menjadi prioritas utama dalam pilihan barang.

Karakteristik responden yang dibagi berdasarkan jumlah kunjungan tiga bulan terakhir terdapat pada Tabel 5. sebanyak empat bagian. Jumlah kunjungan responden terdapat pada jumlah kunjungan terbesar sebanyak dua kali sebesar 76 responden $(38 \%)$ dan kedua pada jumlah kunjungan yang lebih dari tiga kali yakni sebesar 64 responden (32\%) responden. Umumnya responden menyukai kenyamanan belanja, promosi yang didapat dan insentif lain.

\section{Deskripsi Variable-Variabel Penelitian}

\section{Atribut Supermarket}

Atribut supermarket sebagai faktor pertama diukur dari lima variabel pada penelitian dengan indikator sebagai berikut tertera pada Tabel 6. X 1.1 (Atm) Atmosfir supermarket meliputi fasilitas fisik, suhu, layout, dan display; X1.2 (Lok) lokasi toko kemudahan mencapai, letak strategis, fasilitas transportasi; X1.3 (Fas) fasilitas kemudahan, parkir, pembayaran, pengembalian barang; X1.4 (layan) layanan pramuniaga responsif, empathi, reliabel, keramahan; X1.5 (Merchan) barang dagangan, keaneka ragaman, harga, merek dan model.

Secara keseluruhan pada variabel pertama yakni atribut supermarket didapatkan dengan nilai rata-rata keseluruhan sebesar 3,70

Berdasarkan pada Tabel 6, bila lebih jauh kalau dicermati untuk per item indikator, para responden mempersepsikan bahwa atmosfir yang meliputi fasilitas fisik, suhu, layout, dan display di supermarket memiliki nilai rata-rata yang relatif tinggi sebesar 3,81 , namun masih terdapat $4 \%$ para responden mempersepsikan bahwa atmosfir supermarket dari bangunan fisik tidak lengkap, suhu udara tidak segar, layout tidak tertata rapi dan dan display dan interior tidak menarik.

\section{Motif Belanja Hedonik.}

Motif belanja hedonik merupakan variabel kedua pada penelitian dengan pengertian stimuli yang menseleksi kualitas lingkungan belanja dari sisi kenikmatan (enjoyment) yang dirasakan, rasa tertarik akibat pandangan mata (visual appeal) dan rasa lega (escapism) terdiri atas enam indikator pengukur yakni: pertama, Y1.1. Adventure shopping (belanja adalah tantangan, suatu sensasi, menggembirakan, masuk lingungan universal yang menyenangkan); kedua Y1.2. Social shopping (sosialisasi adalah tujuan utama dari pembelanja ketika mereka pergi belanja); ketiga Y1.3 Gratification shopping (kehidupan yang 
kompleks saat ini dan tingkat stres meningkat dimasyarakat. Beberapa orang belanja untuk menghilangkan stress); keempat Y1.4 Idea Shopping (berbelanja memberikan pengetahuan baru perkembangan trend baru dan model baru); kelima Y1.5 Role shopping (peranan belanja direfleksikan dalam kenikmatan, dipengaruhi oleh perasaan dan keadaan hati) dan keenam Y1.6. Value shopping (beberapa orang belanja untuk menemukan barang yang baik dan bernilai bagi dirinya).

Secara keseluruhan pada variabel Motif belanja hedonik memiliki nilai rata-rata sebesar 3,44; hal ini menyatakan bahwa motif belanja responden sebagian besar ditentukan oleh nilai indikator tertinggi yakni value. Telaah lebih lanjut untuk indikator pertama petualangan belanja (adventure shopping) yang terdiri atas belanja adalah tantangan, ketika belanja ada sensasi yang berkesan dan belanja membuat hati gembira; dengan nilai rata-rata 3,17 dengan kategori cukup $(2,55-3,35)$.

Hal ini memberikan gambaran bahwa petualangan belanja di supermarket tidak berkaitan dengan keinginan responden untuk berbelanja. Responden yang menyatakan sangat tidak setuju dan tidak setuju bahwa saat belanja akan memberikan petualangan tersendiri bagi konsumen dengan jumlah 46 responden $(23 \%)$ sedangkan yang menyatakan bahwa belanja memiliki petualangan tersendiri terdapat sebanyak 76 respondden (38\%). Namun kebanyakan responden berada pada kategori netral sebanyak 78 responden, hal ini memberikan gambaran bahwa petualangan belanja tidak mendapat respon yang baik bagi konsumen atau mengadakan transaksi belanja di supermarket Carrefour, Hypermart, dan Giant/Hero.

\section{Motif Belanja Utilitarian.}

Motif belanja Utilitarian merupakan variabel ketiga pada penelitian dengan pengertian dorongan dalam diri orang untuk evaluasi kognitif suatu tingkatan motif seseorang untuk mendapatkan produk dan jasa layanan yang berkualitas didalam supermarket dan efisiensi penggunaan waktu dan tenaga terdiri atas dua indikator pengukur yakni: pertama, Y2.1 kualitas barang Produk yang dijual disupermarket berkualitas baik, mudah dicari dan diambil, diproses dengan baik; kedua, Y2.2 Kualitas layanan (Wiraniaga akan memberi pertolongan, perhatian, menawarkan pelayanan yang terbaik, tidak merasa disibukkan oleh pembeli yang bertanya). Secara keseluruhan pada variabel motif belanja utilitarian memiliki nilai rata-rata sebesar 3,73 (kategori baik.

Hal ini memberikan arti bahwa produk-produk yang ditawarkan di supermarket telah memiliki kualitas yang memadai bagi responden, disamping itu juga responden mempersepsikan bahwa produk yang tersedia mudah dicari dan diambil serta telah diproses dengan baik.

Tabel 7. Distribusi Frekuensi pada variabel Motif Belanja Hedonik

\begin{tabular}{|c|c|c|c|c|c|c|c|c|c|c|c|c|c|}
\hline \multirow{3}{*}{ Item-item } & \multicolumn{10}{|c|}{ Skor } & \multirow{2}{*}{\multicolumn{2}{|c|}{ Total }} & \multirow{3}{*}{ Rata-rata } \\
\hline & \multicolumn{2}{|c|}{1} & \multicolumn{2}{|c|}{2} & \multicolumn{2}{|c|}{3} & \multicolumn{2}{|c|}{4} & \multicolumn{2}{|c|}{5} & & & \\
\hline & f & $\%$ & f & $\%$ & $\mathbf{F}$ & $\%$ & $\mathbf{F}$ & $\%$ & $\mathbf{F}$ & $\%$ & $\mathbf{F}$ & $\%$ & \\
\hline Y1.1. Adventure & 6 & 3 & 40 & 20 & 78 & 39 & 70 & 35 & 6 & 3 & 200 & 100 & 3,17 \\
\hline Y1.2. Social & 4 & 2 & 29 & 15 & 70 & 35 & 80 & 39 & 17 & 9 & 200 & 100 & 3,28 \\
\hline Y1.3 Gratification & 3 & 2 & 25 & 13 & 74 & 37 & 86 & 43 & 12 & 6 & 200 & 100 & 3,38 \\
\hline Y1.4 Idea & 3 & 2 & 34 & 17 & 74 & 37 & 77 & 38 & 12 & 6 & 200 & 100 & 3,31 \\
\hline Y1.5 Role & 0 & 0 & 14 & 7 & 28 & 14 & 126 & 63 & 32 & 16 & 200 & 100 & 3,71 \\
\hline Y1.6 Value & 1 & 1 & 2 & 1 & 51 & 26 & 99 & 48 & 47 & 24 & 200 & 100 & 3,78 \\
\hline Rata-rata frekuensi & & & & & & & & & & & & & \\
\hline
\end{tabular}

Tabel 8. Distribusi Frekuensi pada variabel Motif Belanja Utilitarian

\begin{tabular}{|c|c|c|c|c|c|c|c|c|c|c|c|c|c|}
\hline \multirow{3}{*}{ Item-item } & \multicolumn{10}{|c|}{ Skor } & \multirow{2}{*}{\multicolumn{2}{|c|}{ Total }} & \multirow{3}{*}{ Rata-rata } \\
\hline & \multicolumn{2}{|c|}{1} & \multicolumn{2}{|c|}{2} & \multicolumn{2}{|c|}{3} & \multicolumn{2}{|c|}{4} & \multicolumn{2}{|c|}{5} & & & \\
\hline & f & $\%$ & f & $\%$ & $\mathbf{F}$ & $\%$ & $\mathbf{F}$ & $\%$ & $\mathbf{F}$ & $\%$ & $\mathbf{F}$ & $\%$ & \\
\hline Y2.1. Kualitas Produk & 0 & 0 & 6 & 3 & 38 & 19 & 151 & 75 & 5 & 3 & 200 & 100 & 3,77 \\
\hline $\begin{array}{l}\text { Y2.2. Kualitas Layanan } \\
\text { Rata-rata frekuensi }=3,73\end{array}$ & 0 & 0 & 1 & 1 & 56 & 28 & 136 & 67 & 7 & 4 & 200 & 100 & 3,68 \\
\hline
\end{tabular}

Tabel 9. Distribusi Frekuensi pada variabel Loyalitas Pembelanja

\begin{tabular}{|c|c|c|c|c|c|c|c|c|c|c|c|c|c|}
\hline \multirow{3}{*}{ Item-item } & \multicolumn{10}{|c|}{ Skor } & \multirow{2}{*}{\multicolumn{2}{|c|}{ Total }} & \multirow{3}{*}{ Rata-rata } \\
\hline & \multicolumn{2}{|c|}{1} & \multicolumn{2}{|c|}{2} & \multicolumn{2}{|c|}{3} & \multicolumn{2}{|c|}{4} & \multicolumn{2}{|c|}{5} & & & \\
\hline & $\mathbf{f}$ & $\%$ & $\mathbf{f}$ & $\%$ & $\mathbf{F}$ & $\%$ & $\mathbf{F}$ & $\%$ & $\mathbf{F}$ & $\%$ & $\mathbf{F}$ & $\%$ & \\
\hline Y2.1. Beli ulang & 2 & 1 & 21 & 11 & 57 & 28 & 114 & 57 & 6 & 3 & 200 & 100 & 3,51 \\
\hline Y2.2. Pengeluaran lebih & 0 & 0 & 14 & 7 & 88 & 44 & 89 & 44 & 9 & 5 & 200 & 100 & 3,47 \\
\hline Y2.2. Rekomendasi & 0 & 0 & 20 & 10 & 75 & 38 & 98 & 49 & 7 & 4 & 200 & 100 & 3,46 \\
\hline Rata-rata frekuensi $=3,48$ & & & & & & & & & & & & & \\
\hline
\end{tabular}


Tabel 10. Hasil Pengujian Hipotesis Penelitian

\begin{tabular}{|c|c|c|c|c|c|}
\hline Arah Jalur & Koefisien Regresi & S.E. & C.R. & $\mathbf{P}$ & Sig $5 \%$ \\
\hline Atribut supermarket (X1) & & & & & \\
\hline Belanja Hedonik $(\mathrm{Y} 1)$ & $\gamma_{1}=0,515$ & 0,164 & 5,716 & 0,000 & 0,05 \\
\hline Atribut supermarket (X1) & & & & & \\
\hline Belanja Utilitarian $(\mathrm{Y} 2)$ & $\gamma_{2}=0,687$ & 0,108 & 5,287 & 0,000 & 0,05 \\
\hline Atribut supermarket (X1) & & & & & \\
\hline Loyalitas Pembelanja (Y3) & $\gamma_{3}=0,398$ & 0,163 & 3,055 & 0,000 & 0,05 \\
\hline Belanja Hedonik (Y1) & & & & & \\
\hline Loyalitas Pembelanja (Y3) & $\beta_{1}=0,283$ & 0,058 & 3,392 & 0,000 & 0,05 \\
\hline Belanja Utilitarian (Y2) & & & & & \\
\hline Loyalitas Pembelanja (Y3) & $\beta_{2}=0,286$ & 0,194 & 2,221 & 0,000 & 0,05 \\
\hline
\end{tabular}

Sumber: Data primer diolah (2010)

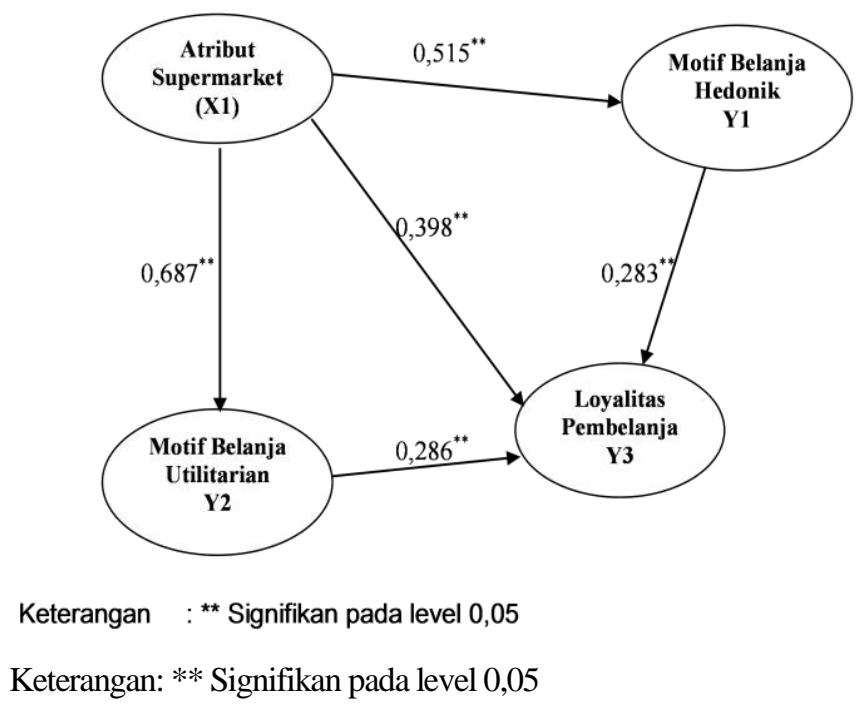

\section{Loyalitas Pembelanja Supermarket.}

Secara keseluruhan pada variabel loyalitas pembelanja supermarket memiliki nilai rata-rata sebesar 3,48 dengan kategori baik, hal ini menyatakan bahwa loyalitas pembelanja supermarket atau responden dapat memberikan benefit yang baik bagi supermarket antara lain dapat memberikan pembelian kembali, rekomendasi ke konsumen lainnya dan responden juga membelanjakan uang yang relatif lebih.

Bila dilihat persetiap item pertanyaan maka untuk indikator pertama yakni memastikan bahwa responden akan melakukan pembelian kembali dengan nilai rata-rata 3,51 dikategorikan baik.
Hal ini memberikan gambaran bahwa responden akan melakukan transaksi belanja ke supermarket di Carrefour,

\section{Pengujian Hipotesis}

Berikut ini adalah uraian hasil uji terhadap 5 buah hipotesis utama yang diajukan pada penelitian. Pemakaian lambang gamma $(\gamma)$ menunjukkan besar pengaruh dari konstruk eksogen terhadap endogen $(\mathrm{H} 1, \mathrm{H} 2$ dan $\mathrm{H} 3)$, sedangkan lambang beta $(\beta)$ menunjukkan besar pengaruh dari konstruk endogen terhadap endogen (H4 dan H5). Tabel 10 adalah ringkasan hasil ketiga pengujian hipotesis. 
Hipotesa 1: Koefisien gamma $\left(\gamma_{1}\right)$ sebesar 0,515 dengan C.R. sebesar 5,716 dan p-value 0,000 telah menunjukkan bukti bahwa koefisien regresi yang diperoleh adalah berbeda dengan nol. Atribut supermarket berpengaruh terhadap motif belanja hedonik diterima hingga taraf signifikansi 0,05 Hipotesa pertama diterima.

Hipotesa 2: Koefisien gamma $\left(\gamma_{2}\right)$ sebesar 0,687 dengan C.R. sebesar 5,287 dan P sebesar 0,000 telah menunjukkan bukti bahwa koefisien regresi yang diperoleh adalah berbeda dengan hipotesis nol. Atribut supermarket berpengaruh secara signifikan terhadap motif belanja utilitarian dapat diterima hingga taraf signifikansi 0,05 . Secara umum koefisien ini telah dapat menjelaskan bahwa peningkatan belanja utlitarian disebabkan oleh peningkatan atribut supermarket, maka dengan demikian dapat dihasilkan kesimpulan bahwa atribut supermarket berpengaruh signifikan terhadap motif belanja utilitarian.

Hipotesa 3: Koefisien gamma $\left(\gamma_{3}\right)$ sebesar 0,398 dengan C.R. sebesar 3,055 dan P sebesar 0,000 telah menunjukkan bukti bahwa koefisien regresi yang diperoleh adalah berbeda dengan hipotesis nol. Atribut supermarket berpengaruh signifikan terhadap loyalitas pembelanja di supermarket dapat diterima hingga taraf signifikansi 0,05 . Secara umum koefisien ini telah dapat menjelaskan bahwa peningkatan loyalitas pembelanja supermarket, maka dengan demikian dapat dihasilkan kesimpulan bahwa atribut supermarket berpengaruh signifikan terhadap loyalitas pembelanja supermarket.

Hipotesa 4: Koefisien beta $\left(\beta_{1}\right)$ sebesar 0,283 dengan C.R. sebesar 3,392 dan P sebesar 0,000 telah menunjukkan bukti bahwa koefisien regresi yang diperoleh adalah berbeda dengan hipotesis nol. Motif belanja hedonik berpengaruh signifikan terhadap loyalitas pembelanja di supermarket dapat diterima hingga taraf signifikansi 0,05 . Secara umum koefisien ini telah dapat menjelaskan bahwa peningkatan loyalitas pembelanja di supermarket disebabkan oleh peningkatan belanja hedonik, maka dengan demikian dapat dihasilkan kesimpulan bahwa motif belanja hedonik berpengaruh terhadap loyalitas pembelanja di supermarket.

Hipotesa 5: Koefisien beta $\left(\beta_{2}\right)$ sebesar 0,286 dengan C.R. sebesar 2,221 dan P sebesar 0,000 telah menunjukkan bukti bahwa koefisien regresi yang diperoleh adalah berbeda dengan hipotesis nol. Motif belanja utilitarian berpengaruh terhadap loyalitas pembelanja di supermarket dapat diterima hingga taraf signifikansi 0,05. Secara umum koefisien ini telah dapat menjelaskan bahwa peningkatan loyalitas pembelanja di supermarket disebabkan oleh peningkatan belanja utilitarian, maka dengan demikian dapat dihasilkan kesimpulan bahwa motif belanja utilitarian berpengaruh signifikan terhadap loyalitas pembelanja di supermarket.

\section{KESIMPULAN DAN SARAN}

\section{Kesimpulan}

Berdasarkan hasil analisis data dan pembahasan sebelumnya, maka temuan penelitian dapat disimpulkan sebagai berikut:

1. Atribut supermarket berpengaruh positif dan signifikan terhadap motif belanja hedonik pembelanja supermarket di Surabaya, menunjukkan bahwa atribut supermarket yang terdiri fasilitas fisik tentang penerangan mall, warna mall, musik, suhu, layout, dan display yang memiliki pengaruh terhadap dorongan dari dalam diri pembelanja dari sisi emosi pembelanja.

2. Atribut supermarket berpengaruh positif dan signifikan terhadap motif utilitarian, hal ini memberikan petunjuk bahwa ketersediaan yang meliputi dorongan lingkungan. Konsumen mengevaluasi supermarket berdasarkan manfaat yang diterima mereka, dengan logika berpikir yang rasional mengevaluasi fungsi belanja yang efisien dan memenuhi kebutuhan mereka. Hasil analisa data ditunjukkan bahwa terdapat pengaruh positif atribut supermarket terhadap motif belanja utilitarian konsumen melihat atribut supermarket menjadi stimuli konsumen untuk mempertimbangkan fungsi belanja yang realistis dan logis.

3. Atribut supermarket stimulus yang dalam hal ini berupa ambiance, design dan Social. Respon konsumen berupa perilaku yang direfleksikan dalam loyalitas pembelanja supermarket berupa waktu yang diluangkan didalam supermarket untuk mengeksplorasi supermarket, pembelian kembali dan mengeluarkan uang untuk belanja lebih banyak. berupa, faktor kenyamanan lebih pada elemen yang non visual seperti tempat yang cenderung pada kenyamanan konsumen. Rancang bangun adalah atribut yang merangsang dan mewakili elemen visual seperti tempat yang cenderung untuk berada pada pengenalan konsumen . Faktor sosial adalah atribut persepsi citra supermarket dibenak konsumennya meliputi kualitas produk dan layanan, keberadaan karyawan dan konsumen dalam lingkungan supermarket. Berdasarkan hasil analisa data bahwa didapatkan hasil pengaruh atribut supermarket terhadap loyalitas pembelanja supermarket dengan signifikan Atribut supermarket berpengaruh langsung dan arah positif serta signifikan. 
4. Motif belanja hedonik berpengaruh positif dan signifikan terhadap loyalitas pembelanja supermarket, evaluasi afektif yang menseleksi kualitas lingkungan belanja dari sisi kenikmatan yang dirasakan, rasa tertarik akibat pandangan mata dan rasa lega menjadi pertimbangan konsumen Surabaya untuk loyal pada Supermarket.

5. Motif belanja utilitarian berpengaruh signifikan terhadap loyalitas pembelanja supermarket di Surabaya, evaluasi kognitif suatu tingkatan motif Utilitarian konsumen supermarket di Surabaya untuk mendapatkan produk dan jasa layanan yang berkualitas didalam supermarket dan efisiensi penggunaan waktu dan tenaga untuk loyal pada Supermarket.

\section{Saran}

Berdasarkan hasil penelitian, peneliti memberikan beberapa hal yang perlu disempurnakan baik oleh praktisi maupun teoritisi, antara lain:

1. Atribut sebagai stimulus sebagai variabel yang penting hendaknya perlu diperhatikan terutama yang mendapat bobot tertinggi seperti fasilitas, kemudahan parkir, pembayaran dan pengembalian barang.

2. Motif belanja Hedonik yang mempunyai bobot tertinggi yang perlu diperhatikan idea shopping berbelanja memberikan pengetahuan dan perkembangan tren baru dan model baru pengelola supermarket hendaknya selalu mencari hal yang inovatif untuk produk.

3. Motif belanja utilitarian mempunyai bobot tertinggi yakni kualitas barang, produk yang dijual disupermarket berkualitas baik, mudah dicari dan diambil diproses dengan baik pihak pengelola supermarket perlu mengevaluasi produk dan layout barangnya.

\section{DAFTAR PUSTAKA}

Arnold, M.J. and Reynolds, K.E., 2003, "Hedonic shopping motivations", Journal of Retailing, vol. 79, pp. 77-95

Assael, H. 1991, Consumer behavior and marketing Action $2^{\text {nd }}$ edition, USA: PWS, KENT.

Arbucle, J.L. Wothke, W., 1999, Amos 4.0 User's Guide: SPSS, Chicago: Small waters corporation.

Babin, B.J., Darden, W.R. and Griffin, M., 1994, "Work and/or fun: measuring hedonic and utilitarian value", Journal of Consumer Research, vol. 20, pp. 644-56.

Baker, J Grewal, D. and Parasuraman, 1994, The influence of store Environment on quality inferences and Store image. Journal of the Academy of Marketing science, vol. 22(4), pp. 328-339.

Baker, J. Parasuraman, A., Grewal, D. and Voss, G., 2002, The influnceof multiple store environment cues on perceived merchandise value and patronage intentions', Journal of Marketing, vol. 66, no. 2, pp. 120-41.

Bitner, Mj., 1992, "Servicescapes, the impact of physical surroundings on costomers and employees", Journal of Marketing, vol 56, No. 2, pp. 57-77.

Broune, M.W. and Cudeck, R., 1993, Alternative ways of assessing model fit, in K.A. Bollen and J.S Long (Eds), testing structural equation models, California: Sage published.

Chaudhuri, A. and Holbrook, M.B., 2001, The chain of effects from brand trust and brand effect to brand performance: the role of brand loyalty, Journal Marketing Vol. 65, pp. 81-93.

Chitturi Ravindra, Rajagopal Raghunathan, \& Vijay Mahajan, 2008, Delight by design: the role of Hedonic versus Utilitarian benefit. Journal of Marketing vol. 72.

Cooper, Donald R. and C. William Emory, 1995, Business Research Methods, Fifth edition, Chicago: Richard D. Irwin inc.

Dharmanesta, B.S., 1999, Loyalty pelanggan. Sebuah kajian konseptual sebagai Panduan peneliti. Jurnal ekonomi dan bisnis Indonesia, vol. 14 No. 3, pp. 73-88.

Donovan, R.J., Rositer, J.R. Marcoolyn, G. and Nesdale, A., 1994, "Store atmosphere and Purchasing Behavior". Journal of Retailing, 70(3), pp. 283-294.

Donovan, R.J. and Rositter, J.R., 1982, "Store atmosphere; an Environmental Psychology Approach" journal of Retailing, vol. 58, pp. 34-57.

Dunette, Marvin, W., Wayne, K. Kirchner, 1965, Psychology Applied to Industry, Meredith Publishing Company, New York.

Engel, J.F., Blackwell. R.D. and Miniard, P.W., 1994, Consumer Behavior. $7^{\text {th }}$ ed. Orlando The Dryden Press USA.

Ferdinand, 2002, Structural Equation Modeling Dalam Penelitian Manajemen Aplikasi Modelmodel rumit dalam Penelitian untuk tesis Magister dan Desertasi Doktor edisi 2 Semarang, penerbit Undip.

Fiore An Marie and Kim Jihyun, 2007, "An integrative framework capturing experiental and utilitarian shopping experience", International journal of retailing\&Management, vol. 35, pp. 421-442. 
Gay, L.R. and Diehl, P.L., 1999, Research Methods For Business and Management, New York, Macmillan Publishing company.

Ghozali, Imam, 2005, Aplikasi Analysis Multivariate Dengan Program SPSS, Semarang: Badan penerbit Universitas Diponegoro.

Gounaris, S. and Stathakopoulos, V., 2004, "Antecedents and consequences of brand loyalty an Empirical study", Journal of Brand Management, vol. 11, no. 4, pp. 283-306.

Hair, Jr., J.F., Anderson, R.E., and Black, W.C., 1999, Multivariate data analysis With readings, New York: Macmillan Publishing Company.

Hirschman, E.C. and Holbrook, M.B.,1982, Hedonic Consumtion: Emerging Concept, Journal of Marketing, vol. 16, pp, 92-101.

Hirschman, E.C., 1983, "Predictors of self Projection, Fullfilmment, and Escapism" Journal of Social Psychology, no. 120, p. 63.

ICSC, shopping centre definitions Basic Configurations of type for the USA International Council of Shopping centre.

Jin, B. and Kim, J.O., 2003, ”A typology of Korean discount shoppers: Shopping motives, stores attributes, and outcomes," International journal of service Industry Management, vol. 14, no. 4, pp. 396-419.

Kim, Hye sin, 2006, "Using Hedonic and utilitarian Shopping Motivations to Profile Inner city consumers", Journal of shopping centre research, vol. 13, pp. 58-78.

Koo, D.M., 2003, 'Inter- relationships among stores images, stores satisfaction, and store loyalty among Korea discount retail patrons", Asia Pacific Journal of Marketing and logistics", vol. 15 , no. 4, pp. 42-71.

Kotler Philip, and Keler Kevin, 2006, Marketing Management, 237, $12^{\text {th }}$ edition, USA: Pearson Prentice Hall.

Kotler Philip, and Amstrong, 2004, Marketing Management, eleven edition, USA: Pearson Prentice Hall.

Kotler Philip, and Amstrong, 2004, Marketing Management, eleven edition, USA: Pearson Prentice Hall.

Levy Michael. and Weitz Barton, 2004, Retailing Management, fifth edition, New York: Mc Graw Hill/Irwin.

Lindquist, J.D., 1974-1975, "Meaning of image-a survey of empirical and hypothetical evidence" Journal of retailing, vol. 50, winter, pp. 29-38.

Loudon, David, L. and Albert J. Dela Bitta, 1993, Consumer Behavior, New York: Mc Graw Hill.

Malhotra, K., Naresh, 1999, Marketing research an applied orientation, Third Edition, New Jersey: Prentice Hall International, Inc.
Mehrabian, A. and Russell, J.A., 1974, An approach to Environmental Psychology, In Fisher, Feffrey D., Paul A. Bell, and Andrew Baum 1984 Environmental Psychology, $2^{\text {nd }}$ ed. New York: Holt, Rinchart and Winston.

Miller, Delbert C., 1991, Handbook of Research Design and social Measurement Fifth edition, Sage Puplication

Monroe, 1991, 'Measurement of Consumers', Perceptions of Product Quality, Brand Name and Packaging: Candy Bar Comaprisons by Magnitude Estimation," Journal of Marketing research, vol. 3, pp. 38-41.

Mowen, J.C. and M. Minor, 1995, Consumer behavior. Boston: USA Irwin: Mc Graw Hill.

Nazir, Moh., 2003, Metode Penelitian, cetakan ketiga, Jakarta: Ghalia Indonesia.

Neal, C, Quster P. and Hawkin, D., 2004, Consumer Behavior: Implications for marketing strategy, North Ryde, NSW: McGraw Hill.

Neo, Linda Wee Keng,and Tong Kok Wing, 2005, The 4 RS Asian Shopping Management. New York: McGraw Hill.

Nguyen Trang. T.M., Nguyen Tho, D, and Barrett, J. Nigel, 2007, "Hedonic shopping motivations, supermarket attributes, and shopper loyalty in transitional markets." Asia pacific Journal of Marketing, vol. 19, no. 3.

Oliver, 1997, Satisfaction: A Behavioral Perspective on the consumer, New York: Irwin, McGrawHill.

Oliver Richard L.,1999, Whence Consumer Loyalty, Journal of Marketing, Vol. 63.

Peter, J. Paul dan Jerry C. Olson, 2002, Perilaku konsumen dan strategi pemasaran. Jakarta: Erlangga.

Raju, P.S., 1980, "Optimum Stimulation Level: Its Relationship to personality, Demographics, and Exploratory Behavior", Journal of Consumer Research, vol. 7, no. 3, p. 272.

Schifman, L.G., and Kanuk, L.L., 1997, Consumer behavior $4^{\text {th }}$ editions, Upper Saddle River, New Jersey: Prentice Hall.

Schifman, L.G. and Kanuk, L.L., 2004, Consumer behavior, $6^{\text {th }}$ editions, Upper Saddle River, New Jersey: Prentice Hall.

Sekaran, Uma, 2003, Research methods for business, New York: John Wiley \& Sons, Inc.

Singh Renu, 2006, An empirical investigation into the effects of shopping motivation on store environment value relationship, Desertation, The Florida state University:USA.

Solomon, M.R., 2002, Consumer behavior: buying, having,and being, New Jersey :Prentice Hall, upperSaddle River.

Timo Rintamaki, Kanto Anti, Kusula Hannu, Spence Mark, T., 2006 "Decomposing the value of 
departement store shopping into utilitarian, hedonic and social dimensions" International Journal of retail \& distribution Management, vol. 34 .

Woodruff, R.B., 1997, "Customer value the next source for comtetif advantage" Journal of the academy Marketing Science, vol. 25, no. 2, pp. 139-53.
Zeitham, Berry, and Parasuraman, 1996, The behavioral Consequences of service Quality New York: McGraw Hill Irwin.

Zeitham, Bitner, M.J. Gremler, Dwaine, D. 2006, Services Marketing, Integrating Customer Focus Across the Firm, $4^{\text {th }}$ edition New York: McGraw Hill Irwin. 